\title{
SCARECROW PRESS
}

\section{Announces Republication of}

\section{THE CHILDREN OF IMMIGRANTS \\ IN SCHOOLS}

With an Introductory Essay

By

Francesco Cordasco

Originally published as

Volumes 29-33 of the

REPORTS OF THE

IMMIGRATION COMMISSION

(Senator William P. Dillingham, Chairman)

5 Vols. (3,880 pages) 1911 (Reprint 1970)

ISBN 0-8108-0345-3

5 Volumes:

Special Pre-publication Offer: $\$ 80.00$

THE CHILDREN OF IMMIGRANTS IN SCHOOLS is a vast repository of data on the educational history of immigrant children in America and the response of the American educational system to their needs.

This impressive, five-volume report, now republished in its entirety, provides detailed analyses of the backgrounds, nativity, school progress, and home environments of school children in 32 American cities. The wealth of data reported assists historians, social scientists, and educators in piecing together the intricate mosaic of late 19th century and early 20th century American life. It helps to explain subsequent American history and educational philosophy and sheds light on contemporary urban and minority problems.

Dr. Francesco Cordasco, Professor of Education at Montclair State College, has provided a new introductory essay.

Send your order to:

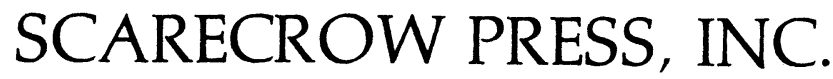

52 Liberty St., (P.O. Box 656) Metuchen, N.J. 08840 


\section{HERBART AND HERBARTIANISM}

\section{An Educational Ghost Story}

\section{Harold B. Dunkel}

George Friedrich Herbart (1776-1841), traditionally an important figure in the history and philosophy of education, actually had little connection with Herbartianism, the soifce of his fame. Dunkel traces Herbart's transformation first by German and later by Amerisian educational ghostwriters, and analyzes the dramatic shifts in his status from obscurity to immense popularity and back to oblivion. Twenty five years after his death, a Leigigig professor Tuiskon Ziller and his student Wilhelm Rein made extensive deletions, additions, and alterations in Herbart's views as they molded his ideas to fit their own interests and circumstances. Charles DeGarmo, Charles McMurry, and Frank McMurry were chigfly responsible for bringing "Herbartianism" to America and making still further change कु in the original doctrine.

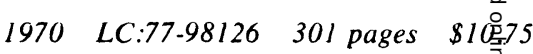

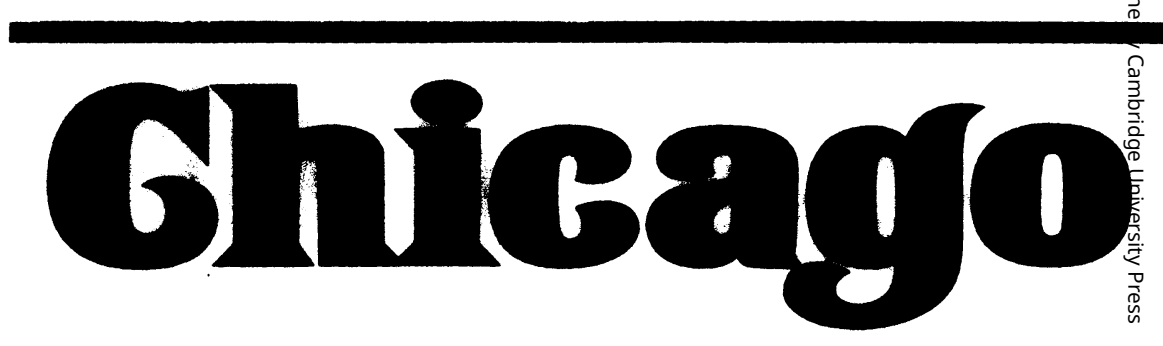

\section{THE EMERGENCE OF THE AMERICAN UNIVERSITY}

\section{Laurence R. Veysey}

"This is one of the most important and stimulating books published in American intellectual and cultural history within the last decade."-John Braeman, Journal of Higher Education.

"... Professor Veysey`s study deserves a wide reading."-Frank M. Cordasco, History of Education Quarterly.

\section{LC:65-24427 505 pages Cloth \$10.10 Paper $\$ 3.95$}

\section{TOLSTOY ON EDUCATION}

\section{Edited with an introduction by Reginald D. Archambault}

Tolstoy's essays provide a sustained view of one of the most interesting pedagogical ventures of the nineteenth century. Disgruntled with contemporary educational practice and dismayed with the bankruptcy of its theory, Tolstoy founded an experimental school in 1861. His essays, long out of print, deal with the problems of nurturing peasant children as well as future leaders in the Universities. Here the reader will find seeds of radical innovation which came to flower in John Dewey's educational theory.

$$
1967 \text { LC:67-25514 } 360 \text { Pages Cloth \$6.00 Paper \$2.95 }
$$

The University of Chicago Press, Chicago 60637 


\section{COMING IN THE FALL ISSUE OF THE QUARTERLY}

Some English Academies: An Experiment in the Education of Renaissance Gentlemen, by Patricia-Ann Lee

EDUCATION IN COLONIAL NEW ENGLAND

The Transformation of Massachusetts Education $1670-1780$, by Jon Teaford

Education in John Eliot's Indian Utopias, $1646-1675$, by Norman Earl Tanis

\section{NOTES AND DOCUMENTS}

Paul Monroe's Cyclopedia of Education: With Notices of Educational Encyclopedias Past and Present, by William W. Brickman and Francesco Cordasco

DISCUSSION

Useful History and Black Identity, by

Paul H. Mattingly

ESSAY REVIEWS

"Plato on Education: Philosopher or Dramatist?", by Robert Wellman

"The American University: Community, Oasis, Mummy," by James Gilbert

"Education in the British Isles," by James Murphy

"German Mandarins and Weimar Culture," by Sterling Fishman 
